\title{
The first extinct species of Acritus LeConte, 1853 (Histeridae: Abraeinae) from Eocene Baltic amber: a microscopic beetle inclusion studied with X-ray micro-computed tomography
}

\author{
Vitalii I. Alekseev ${ }^{1,2,3}$ and Andris Bukejs ${ }^{4}$ \\ ${ }^{1}$ Shirshov Institute of Oceanology, Russian Academy of Sciences, Nahimovskiy prospekt 36, Moscow 117997, Russia \\ ${ }^{2}$ Institute of Life Sciences, Immanuel Kant Baltic Federal University, Nevskogo street 14, Kaliningrad 236016, Russia \\ ${ }^{3}$ Kaliningrad Regional Amber Museum, Marshal Vasilevskii square 1, Kaliningrad 236016, Russia \\ ${ }^{4}$ Institute of Life Sciences and Technologies, Daugavpils University, Vienības 13, Daugavpils 5401, Latvia
}

Correspondence: Andris Bukejs (carabidae@inbox.lv)

Received: 26 March 2021 - Revised: 11 June 2021 - Accepted: 17 June 2021 - Published: 8 July 2021

\begin{abstract}
Acritus sutirca sp. nov. is described and illustrated from Eocene Baltic amber on the basis of one adult male specimen. As the first extinct member of the subfamily Abraeinae (Histeridae) and the smallest known fossil histerid specimen, this material was examined using a combination of light microscopy and X-ray microcomputed tomography $(\mu \mathrm{CT})$. Internal features of the abdomen are well preserved, allowing us to study sclerotized parts of the aedeagus and illustrate these structures in detail. The current finding expands the range of known Histeridae diversity from the Eocene (48-34 Ma) "amber forests" of Europe. The absolute size limits and the probable average size for Baltic amber coleopteran inclusions are also briefly discussed (urn:lsid:zoobank.org:pub:A2B174798628-47C7-A8D4-3E0789BF088B).
\end{abstract}

\section{Introduction}

The genus Acritus LeConte, 1853 is nearly cosmopolitan in distribution and comprises more than 120 described extant species worldwide (Kryzhanovskij and Reichardt, 1976; Mazur, 2011), while 16 species are registered in the Recent Palaearctic (Lackner et al., 2015). Representatives of this microhisterid genus occur usually under the bark of deciduous trees and in putrescent wood, as well as in decaying fungi, under stones, and in forest litter. Sometimes, the beetles can be found cohabitating with ants or termites, and they have been sampled in boreholes of bark beetles or in burrows of small mammals (Kryzhanovskij and Reichardt, 1976). The present-day distributional range of several species (e.g. Acritus komai Lewis, 1879) which also occur in anthropogenic habitats may be secondarily widened by accidental human introduction (Lackner, 2013).

Histerid inclusions are scarce in Baltic amber collections (e.g. Klebs, 1910; Hieke and Pietrzeniuk, 1984; Kulicka and Ślipiński, 1996) and are represented by small and easily overlooked specimens. In general, the clown beetles of Eocene Baltic amber are insufficiently studied (Alekseev, 2013, 2017a). The oldest reports of the family from this lagerstätte are not precise and include the notes "Hister" within the "Clavicornia" group (Berendt, 1845; Menge, 1856), as well as "Histeridae" (Helm, 1896). The generic data on clown beetles in Baltic amber were first provided by Klebs (1910), who listed five different specimens from the famous Königsberg amber collection: two specimens belonging to Abraeinae ("Abraeus" and "Acritus"), two belonging to Dendrophilinae ("Bacanius?" and "Carcinops") and one specimen belonging to Histerinae ("Platysoma"). This more or less credible and brief information was repeated later without any significant additions (Spahr, 1981), and the data have been partially supported or supplemented only within the last decade (Alekseev, 2016; Sokolov and Perkovsky, 2020; Alekseev and Bukejs, 2021).

The size of insect inclusions in ambers is often used for morphologic comparison with extant relatives. Sometimes, the size difference between extant and amber forms is interpreted in the context of climate changes (Nadein and 
Perkovsky, 2019) or as an evolutionary trend within the group (Perkovsky and Nel, 2021). Without doubt, the rational and adequate use of data available from fossils should include the size information and is promising. However, it needs to be used for general conclusions with caution. In the current paper, a new microhisterid species of the genus Acritus LeConte, 1853 is described and illustrated from Eocene Baltic amber using X-ray microtomography. The male genitalia are examined and illustrated. It is the first fossil member of this genus and one of the smallest described coleopteran species from this lagerstätte and from Eocene European ambers in general. The problematic of the size range in amber inclusions is briefly discussed as well.

\section{Material and methods}

The material examined is deposited in the collection of the Museum of Amber Inclusions, University of Gdańsk (Poland) (MAIG).

The X-ray micro-CT $(\mu \mathrm{CT})$ observations of specimen were conducted at Daugavpils University, Daugavpils, Latvia, using a Zeiss Xradia 510 Versa system. Scans were performed with a polychromatic X-ray beam at an energy of $30 \mathrm{kV}$ and power of $2 \mathrm{~W}$. Sample to detector distance was set to $12.8 \mathrm{~mm}$, and source to sample distance was set to $23.4 \mathrm{~mm}$. Tomographic slices were generated from 3001 rotation steps through a $360^{\circ}$ rotation, using a $20 \times$ objective, and exposure time during each projection was set to $17 \mathrm{~s}$. Acquired images were binned $(4 \times 4 \times 4)$ giving a voxel size of $1.75 \mu \mathrm{m}$. Images were imported into the Dragonfly PRO (version 2020.2) software platform for interactive segmentation and $3 \mathrm{D}$ visualization. Prior to the full scan, a 23 min warmup scan was conducted with identical stitch parameters, but with reduced rotational steps (201) and exposure time set to $3 \mathrm{~s}$.

The photographs of the specimen were taken using a Leica M205 (stereomicroscope with a camera). Extended depth of field at high magnification was achieved by combining multiple images from a range of focal planes using Leica Application Suite software, and the resulting images were edited to create figures using Adobe Photoshop 7.0 software.

The following references were used for the generic placement of the examined specimen and its comparison with extant and extinct taxa: Wenzel (1955), Kryzhanovskij and Reichardt (1976), Gomy (1994), Lackner (2013), Alekseev (2016), Sokolov and Perkovsky (2020), and Alekseev and Bukejs (2021).

\section{Systematic palaeontology}

Family Histeridae Gyllenhal, 1808

Subfamily Abraeinae MacLeay, 1819

Tribe Acritini Wenzel, 1944
Genus Acritus LeConte, 1853

Subgenus Acritus LeConte, 1853

\section{Remarks}

The specimen under study is assigned to the tribe Acritini within the subfamily Abraeinae based on the following: (1) the prosternum without anterior lobe; (2) body size less than $1.0 \mathrm{~mm}$; (3) metatarsi with four tarsomeres (i.e. tarsal formula 5-5-4); (4) body form oval, not subcylindrical; and (5) pronotum evenly convex, without deep transverse furrow medially. The generic placement and attribution to Acritus is based on a combination of the following characters: (1) eyes present; (2) protibiae setose, without spinules or denticles; (3) scutellar shield small but visible; (4) pygidium without marginal stria; and (5) pronotum with a transverse line of large punctures along the basal margin.

The extant genus Acritus consists of two subgenera: Acritus s. str. with 118 described species and Pycnacritus Casey, 1916 with 9 species (Mazur, 2011). The studied specimen does not have any oblique dorsal striae or vague impressions on the elytra, and it lacks any microsculpture between its fine elytral punctation. Therefore, a newly described fossil species was placed in the nominative subgenus.

\section{Acritus (Acritus) sutirca sp. nov. urn:1sid:zoobank.org:act:81D788F9-A159-45AE- B9CC-CDBCCDEC41A4}

Figs. 1-4

\section{Type material}

Holotype: no. 5541 (MAIG), "HOLOTYPE/Acritus sutirca sp. nov./des. Alekseev V.I. \& Bukejs A. 2021"; adult, male (determined based on micro-CT results). A complete beetle included in a very small, transparent, yellow amber piece with dimensions of $3 \times 2 \mathrm{~mm}$, maximum thickness of $1 \mathrm{~mm}$; and preserved without supplementary fixation but subsequent to study it will be embedded in synthetic resin. The original amber piece (before cutting) included many syninclusions: three specimens of Dolichopodidae (Diptera), two specimens of Sciaridae (Diptera), one female specimen of Chironomidae (Diptera), one male specimen of cf. Ceratopogon sp. (Ceratopogonidae: Diptera, det. R. Szadziewski), one female specimen of cf. Neurohelea cothurnata (Meunier, 1904) (Ceratopogonidae: Diptera, det. R. Szadziewski); and one specimen of Thysanoptera.

\section{Type stratum}

Middle-Late Eocene, 48-34 Ma (Seyfullah et al., 2018; Bukejs et al., 2019; Kasiński et al., 2020; Sadowski et al., 2017, 2020). 

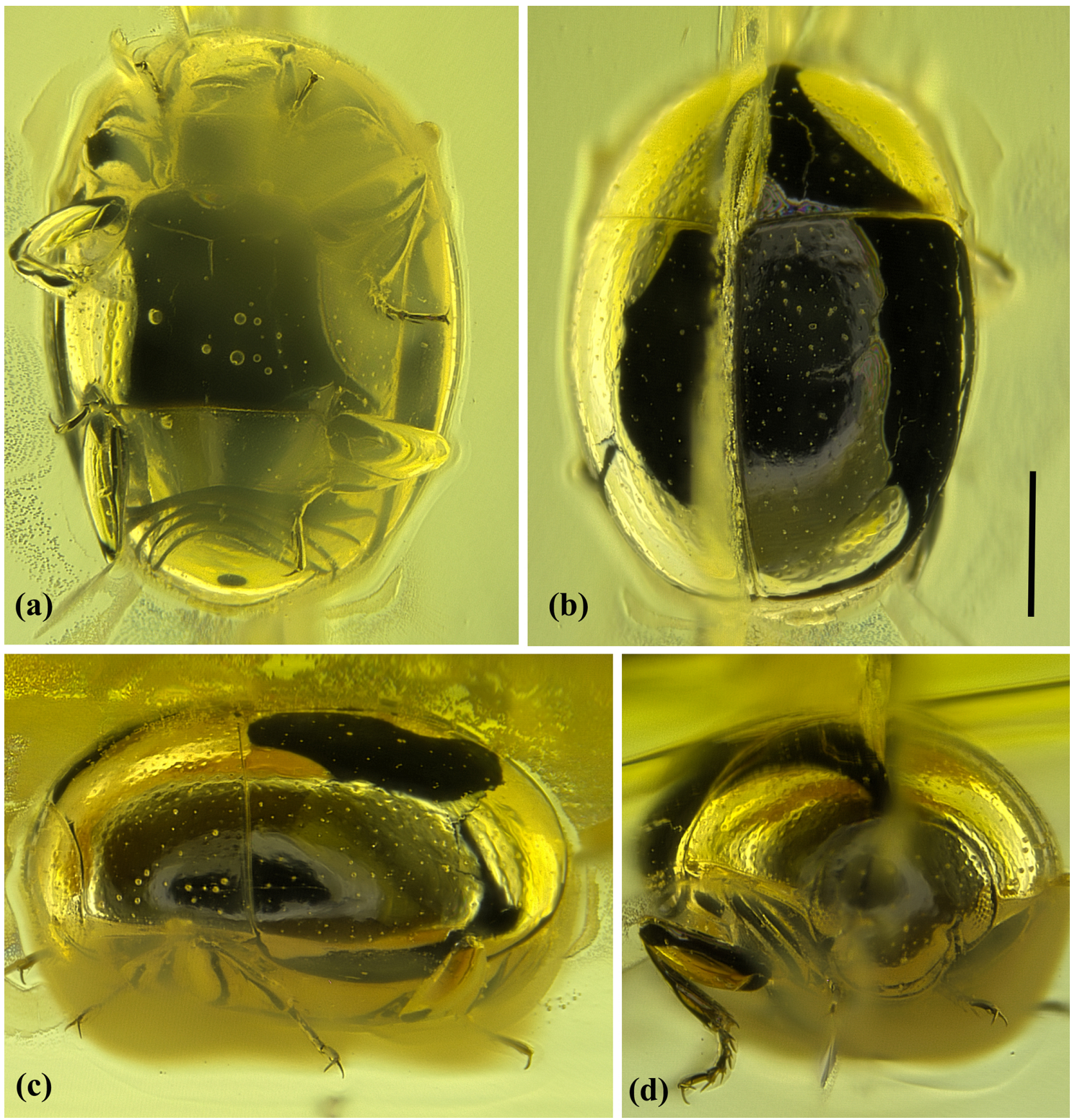

Figure 1. Photomicrographs of Acritus sutirca sp. nov., holotype, no. 5541 (MAIG), habitus: (a) ventral view; (b) dorsal view; (c) left lateral view; (d) frontal view. Scale bar represents $0.2 \mathrm{~mm}$.

\section{Type locality}

Russia, Kaliningrad region, the Sambia Peninsula (Samland).

\section{Description}

Measurements: body length $0.75 \mathrm{~mm}$, body maximum width $0.56 \mathrm{~mm}$; pronotum length $0.28 \mathrm{~mm}$, pronotum maximum width $0.51 \mathrm{~mm}$; elytra length $0.49 \mathrm{~mm}$, elytra maximum combined width $0.56 \mathrm{~mm}$.

Body widely oval, convex; integument unicolorous black (as preserved).
Head large and wide, partially retracted into prothorax, apparently covered with fine punctation. Fronto-clypeal suture absent. Compound eyes moderately large, rounded, slightly convex. Antennae clavate, apparently 9-segmented, short, slightly longer than protibia. Scape large, elongate, clavate; pedicel cylindrical; antennomeres 3-8 transverse; antennal club (formed from fused antennomeres 9-11) without sutures, widely oval, with rounded apex, about as long as antennomeres 3-8 combined.

Pronotum transverse, $1.82 \times$ as wide as long, widest at base. Punctation distinct, small, sparse; punctures round and small; distance between punctures equal to $1.0-3.5 \times$ diameter of one puncture; interspaces smooth. Lateral mar- 


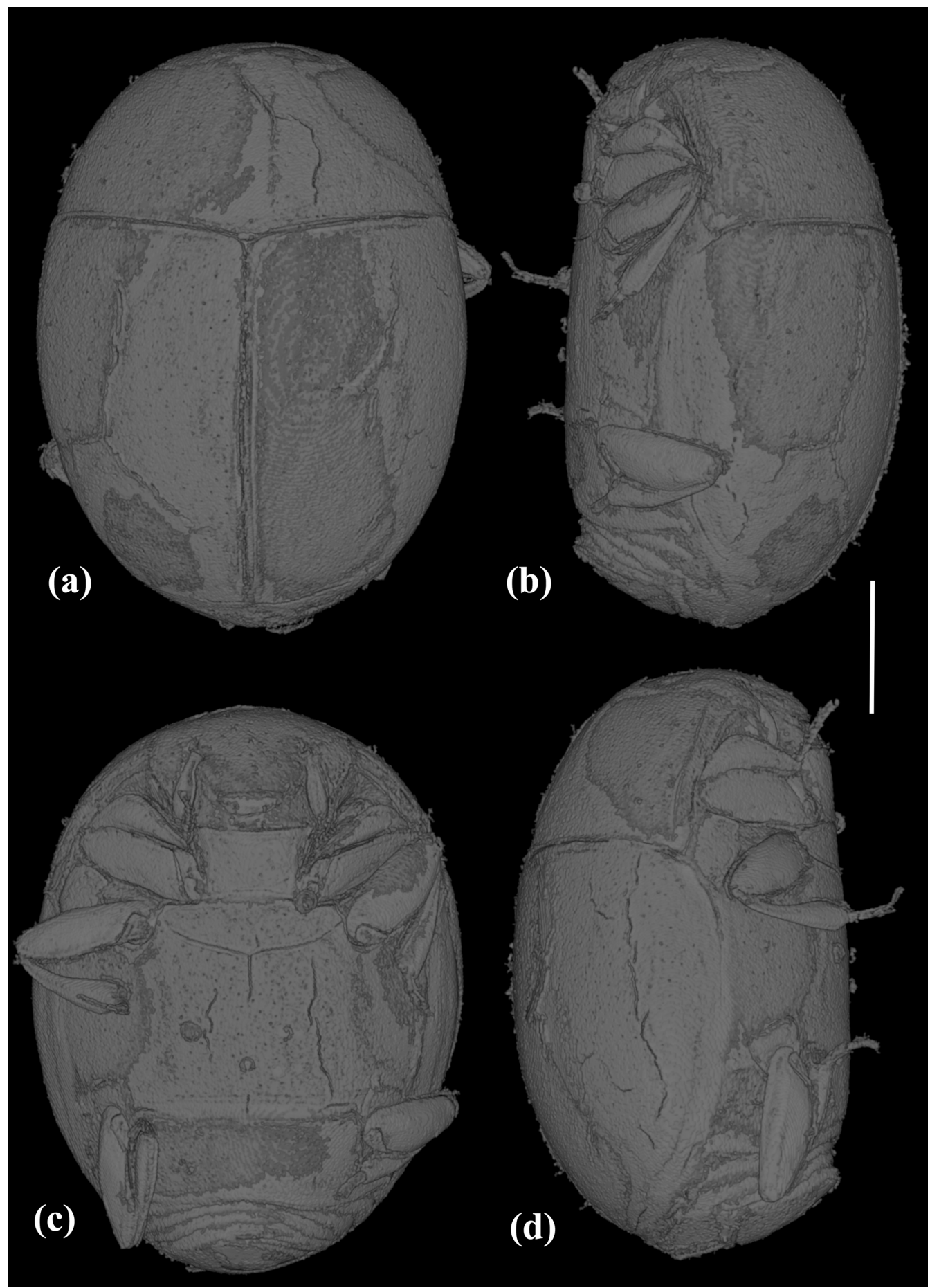

Figure 2. X-ray micro-CT renderings of Acritus sutirca sp. nov., holotype, no. 5541 (MAIG), habitus: (a) dorsal view; (b) left lateral view; (c) ventral view; (d) right lateral view. Scale bar represents $0.2 \mathrm{~mm}$.

gins widely rounded; anterior and posterior margins convex. Anterior angles orthogonal; posterior angles nearly orthogonal. Marginal stria complete. Antescutellar stria absent. Basal pronotal margin with sparse punctures. Prosternum non-lobed anteriorly, transversely trapezoidal in form, with slightly arcuate anterior and posterior margins, moderately convex, without distinct punctation.

Scutellar shield very small, triangular.

Elytra nearly as wide as long, widest anterior to midlength, truncated, not completely covering abdomen; basal 


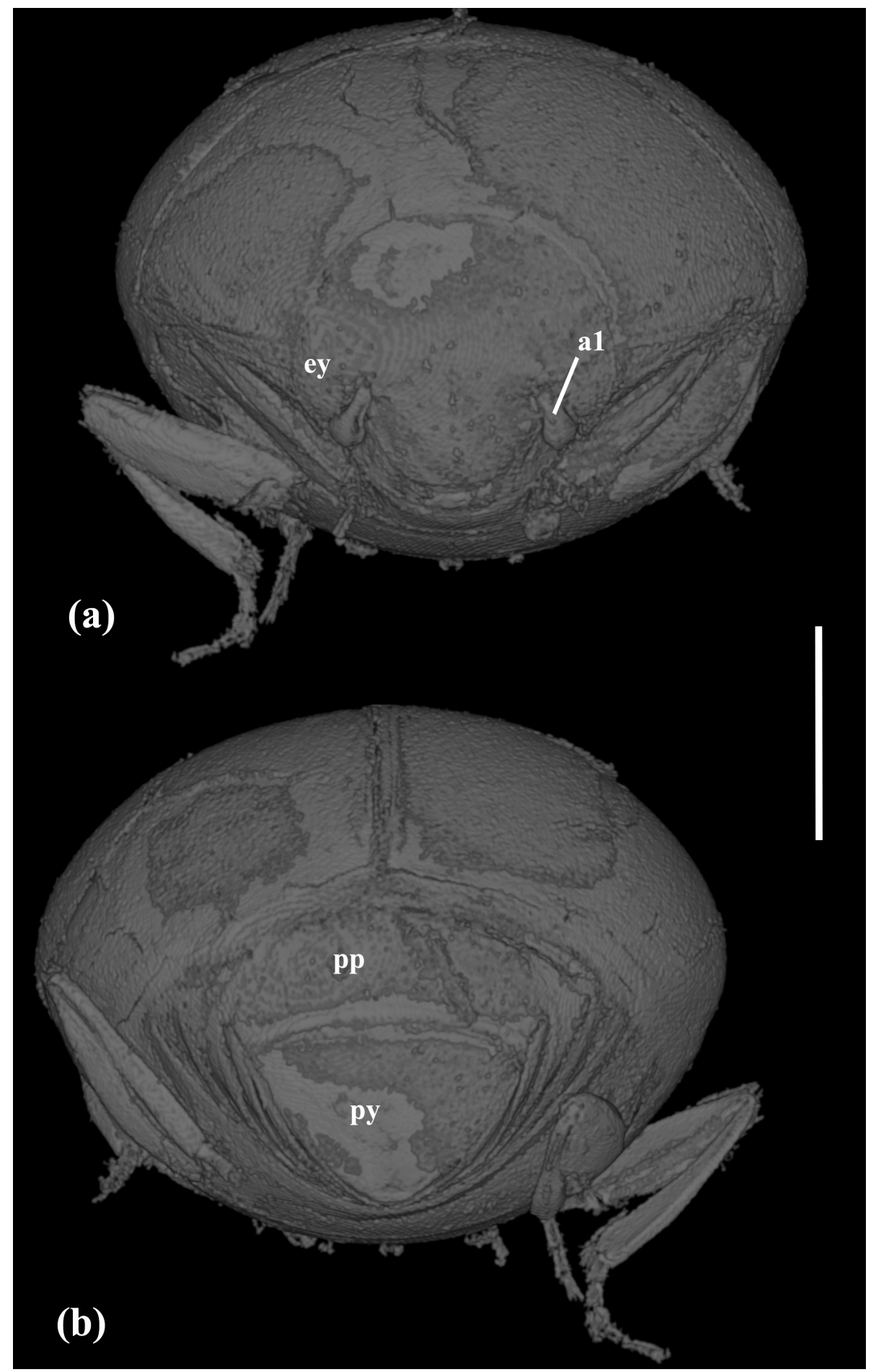

Figure 3. X-ray micro-CT renderings of Acritus sutirca sp. nov., holotype, no. 5541 (MAIG), habitus: (a) frontal view; (b) caudal view. Scale bar represents $0.2 \mathrm{~mm}$. Abbreviations: a1 - antennomere 1 (scape); ey - compound eye; py - pygidium; pp - propygidium. 


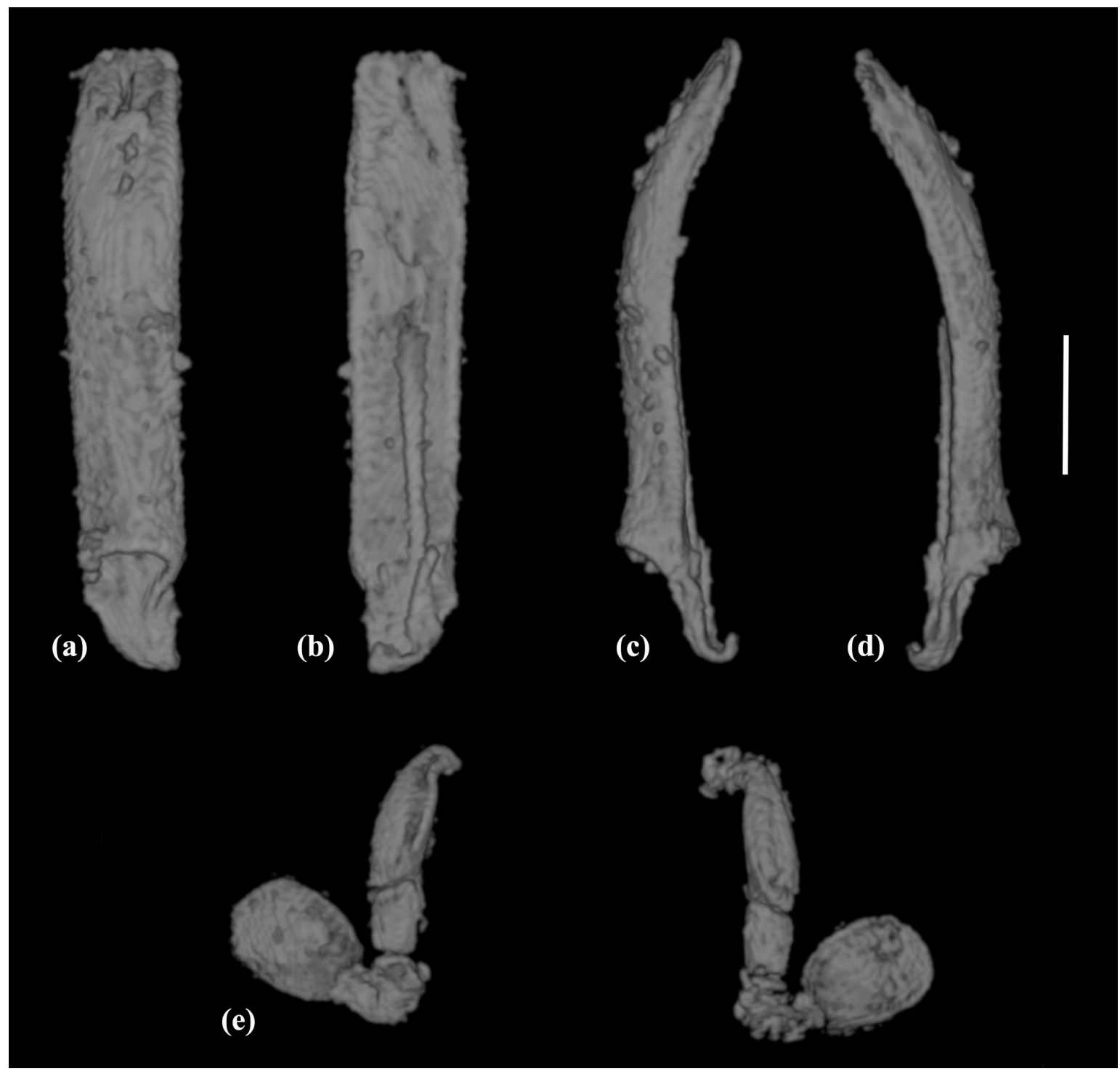

Figure 4. X-ray micro-CT renderings of Acritus sutirca sp. nov., holotype, no. 5541 (MAIG): (a-d) aedeagus in dorsal, ventral view and lateral views; (e) antennae. Scale bar represents $0.1 \mathrm{~mm}$.

margin of elytra almost straight, as wide as pronotal posterior margin; elytral punctation distinct: disc evenly, finely and sparsely punctate; dorsal elytral striae or any impressions absent; marginal stria complete. Mesoventrite almost flat, narrow, about $3.3 \times$ as wide as long, without distinct punctures. Meso-metaventral suture obtusely angulate medially, without punctures. Metaventrite with flat, finely punctate disc; lateral sides with larger punctation, distance between punctures about 2.5-5.0× diameter of one puncture; posterior margin straight. Lateral metaventral stria bent and curved backwards reaching mesepimeron.

Legs rather long. All coxae widely separated, ratio of relative distances between pro-, meso- and metacoxae equal to $4: 7.5: 8.5$. Femora flattened, slightly widened mesally. Tibiae nearly as long as femora; protibia setose, without teeth, slightly dilated in apical portion; meso- and metatibiae narrower, slightly dilated apically, with two thin apical spurs. Tarsi long, slender; pro- and mesotarsi pentamerous, metatarsi tetramerous; ratio of relative lengths of metatarsomeres $1-4$ equal to $17: 8: 8: 20$. Tarsal claws thin, free, simple.

Abdominal ventrite 1 largest, distinctly longer than ventrites 2-5 combined, nearly impunctate (with few punctures laterally), with straight femoral lines across ventrite 1; sutures between ventrites 1-4 arcuate. Pygidium and propygidium visible in ventral and caudal views, glabrous, apparently impunctate.

Aedeagus with almost parallel lateral sides; curved in lateral view; truncate apically (Fig. 4a-d). 


\section{Differential diagnosis}

Acritus (s. str.) sutirca sp. nov. differs from the widely distributed extant Palaearctic A. nigricornis, as well as from $A$. komai Lewis, 1879, A. italicus Reitter, 1904, and many other representatives of the genus in the absence of distinct arcuate transverse antescutellar striae on its pronotal base. The shape of the lateral metaventral stria within the new species is bent and curved backwards, reaching the mesepimeron (a characteristic which is similar to A. nigricornis and different from A. komai). The combination of other characters mentioned in the species description (e.g. body part ratios), as well as details of punctation, should distinguish the new fossil species from all Recent congeners.

Acritus (s. str.) sutirca sp. nov. can easily be distinguished from two dendrophiline histerids that have been described from Baltic amber, Carcinops donelaitisi Alekseev, 2016, and Xestipyge ikanti Alekseev, 2016, in that the new species is distinctly smaller in body size (both mentioned species are about $1.5 \mathrm{~mm}$ long) and based on its lack of dorsal elytral striation. The new species differs from the similar-looking dendrophiline microhisterids that have recently been described from Rovno and Baltic amber (Bacanius kirejtshuki Sokolov and Perkovsky, 2020 and B. gorskii Alekseev and Bukejs, 2021), based on subfamilial and generic characters. These characters include the following: the anteriorly non-lobed transverse prosternum (prosternal lobe present in Bacanius, so the prosternum is longer than it is wide); 4-segmented metatarsi (in contrast to 5-segmented in Bacanius); truncated elytra and partially exposed pygidium (in contrast to the nontruncated elytra completely covering pygidium of Bacanius); and small, triangular scutellar shield (not distinct in Bacanius).

\section{Derivatio nominis}

The species name "sutirca" is based on the generic name Acritus read backwards, and it is used as a noun in apposition.

\section{Discussion}

A list of the smallest adult coleopteran inclusions from Baltic amber was composed few years ago (Alekseev, 2017b). The smallest described beetle from this fossil resin, Micridium groehni Polilov and Perkovsky, 2004 (Ptiliidae), is $0.49 \mathrm{~mm}$ long (Polilov and Perkovsky, 2004). In contrast, the remains of the largest reported Baltic amber beetle inclusion belong to an unnamed representative of the tribe Trichiini (Scarabaeidae), which is $14 \mathrm{~mm}$ long (Alekseev, 2019). The average length of adult beetles in Baltic amber was calculated to be $3.15 \mathrm{~mm}$ based on 300 measured coleopteran inclusions (Alekseev and Turkin, 2007); however, biases and preselection in that sample set are currently under question, and the results should be considered approximate only. The new species described in the current paper, Acritus (s. str.) sutirca sp. nov., is among the smallest beetles described from Baltic amber. It ranks second (after the aforementioned ptiliid $\mathrm{Mi}$ cridium), together with an antlike stone beetle Semnodioceras halticaeforme Schaufuss, 1890.

Resin trapping may be biased toward certain organisms, and amber inclusions tend to be dominated by small forms (Martínez-Delclòs et al., 2004). The upper limit of animal size in amber inclusions is apparently determined by the maximum production of the resiniferous tree (i.e. by the size of the amber container for the inclusion - the larger resin flow is, the larger the possible inclusion) and the ability of larger insects to struggle free from the entombing resin. The lowest limit is controlled by factors that determine the miniaturization of insects and arthropods in general (e.g. Polilov, 2015 ) and is not specific in any respect for amber. In this regard, it is important to note the different systematic groups of Baltic amber arthropods should have different "normal" or "median" sizes of inclusions: Acarina should belong to the class of the smallest inclusions, whereas representatives of Odonata belong to the class of the largest ones. Different types of amber are not equal in distribution of inclusion sizes either, probably because of variation in the viscosity of the resin or durability of the resulting amber (Martínez-Delclòs et al., 2004).

Based on what we currently know, the absolute size limits for Baltic amber adult beetles could be defined as 0.49$20.00 \mathrm{~mm}$, keeping in mind that the upper limit is not clear, because the measured remains are $14 \mathrm{~mm}$ and belong to a beetle thought to be about $20 \mathrm{~mm}$ long (Alekseev, 2019). The probable average, "normal" size for beetle inclusions is about $3 \mathrm{~mm}$ according to Alekseev and Turkin (2007). The marginal zone close to the absolute size limits for coleopteran inclusions in Baltic amber includes two plots: (1) with values 3 times less than average (i.e. $0.49-1.0 \mathrm{~mm}$ ) and (2) with values 3 times larger than average (i.e. 9.00 $20.00 \mathrm{~mm}$ ). We suppose the normal distribution of inclusion body sizes could be distorted by additional filtering, including physical features of the amber itself (e.g. the fragility of large pieces with large inclusions or the layered heterogeneity of amber and probable optical invisibility of smallest inclusions by preliminary observation). The deviation from randomness should be especially high in the zone of the largest inclusions. In modern settings, large insects and vertebrates can escape from the viscous trap provided by resin, or they can be predated before the complete encapsulation (Martínez-Delclòs et al., 2004). The maximum limit of animal inclusion sizes in Baltic amber likely does not exceed $5-6 \mathrm{~cm}$ in theory, and it seems probable that most inclusions above $30 \mathrm{~mm}$ were entombed in resin post-mortem only. Fossil scorpions from Baltic amber are no longer than 19-25 mm (Lourenço, 2009), while the largest nymph of Odonata is preserved as only a partial body $26 \mathrm{~mm}$ in length (Bechly and Wichard, 2008). The largest relatively complete animal inclusion in Baltic amber is a lacertid: the measured remains 
of Succinilacerta succinea specimen are about $40 \mathrm{~mm}$ long with a roughly estimated total length of complete specimen no more than $60 \mathrm{~mm}$ (Borsuk-Bialynicka et al., 1999; Wang and Xing, 2020).

The partial statistical correspondence of inclusion body sizes to the Gaussian normal distribution could be hypothesized based on the currently available data, but it remains an interesting topic for future research, because it needs unbiased sampling and rigorous mathematical modelling to test. Palaeoclimatic interpretations made on the basis of predominantly smaller or larger body size of inclusions in comparison with Recent analogues should be made with caution. Any conclusion about the specimens that occupy the marginal zone close to the upper size limit is weak and not verifiable; meanwhile any conclusions about specimens from the marginal zone close to the lower size limit should be statistically calculated on the basis of a representative sample.

Data availability. All material included in the paper is deposited in the collection of the Museum of Amber Inclusions, University of Gdańsk (Gdańsk, Poland), and all data are included in the description. X-ray microtomography volume renderings of the habitus, antenna, and aedeagus of Acritus (s. str.) sutirca sp. nov., holotype, 5541 (MAIG) are available as Video Supplements.

Video supplement. The videos are available at:

- https://doi.org/10.5446/52938 (Bukejs and Alekseev, 2021a),

- https://doi.org/10.5446/52939 (Bukejs and Alekseev, 2021b),

- https://doi.org/10.5446/52940 (Bukejs and Alekseev, 2021c).

Author contributions. VIA and $\mathrm{AB}$ designed the study and prepared new species description. VIA performed specimen identification and systematic placement. Both authors drafted the manuscript and contributed to the writing and discussion.

Competing interests. The authors declare that they have no conflict of interest.

Disclaimer. Publisher's note: Copernicus Publications remains neutral with regard to jurisdictional claims in published maps and institutional affiliations.

Acknowledgements. We are sincerely grateful to Elżbieta Sontag, the curator of the Museum of Amber Inclusions (University of Gdańsk, Poland), for allowing the study of interesting inclusions under her care and for preparation of photographs, to Kristaps Kairišs (Daugavpils University, Daugavpils, Latvia) for assistance in Xray micro-computed tomography, reconstruction $\mu \mathrm{CT}$ data, preparation volume renderings and $3 \mathrm{D}$ models, to Michael S. Caterino (Clemson, USA) for confirmation of generic placement of the stud- ied specimen, and to Ryan McKellar (Royal Saskatchewan Museum, Regina, Saskatchewan, Canada) for linguistic suggestions on an early version of the manuscript. We thank the reviewers Tomáš Lackner (Bavarian State Collection of Zoology, Munich, Germany) and Michael S. Caterino (Clemson University, Clemson, USA), for their helpful comments and corrections to an earlier version of the manuscript.

Financial support. The study of Vitalii I. Alekseev was done with the support of the state assignment of IO RAS (theme no. 01282021-0012).

Review statement. This paper was edited by Carolin Haug and reviewed by Tomáš Lackner and Michael Caterino.

\section{References}

Alekseev, V. I.: The beetles (Insecta: Coleoptera) of Baltic amber: the checklist of described species and preliminary analysis of biodiversity, Zool. Ecol., 23, 5-12, https://doi.org/10.1080/21658005.2013.769717, 2013.

Alekseev, V. I.: Description of two clown beetles (Coleoptera: Staphyliniformia: Hydrophiloidea: Histeridae) from Baltic amber (Cenozoic, Paleogene, Eocene), Baltic Journal of Coleopterology, 16, 27-35, 2016.

Alekseev, V. I.: Coleoptera from the middle-upper Eocene European ambers: generic composition, zoogeography and climatic implications, Zootaxa, 4290, 401-443, https://doi.org/10.11646/zootaxa.4290.3.1, 2017a.

Alekseev, V. I.: A new species of minute beetle (Coleoptera: Clambidae) from Baltic amber (Paleogene, Eocene), Zootaxa, 4337, 141-145, https://doi.org/10.11646/zootaxa.4337.1.8, 2017b.

Alekseev, V. I.: First inclusion of a trichiine beetle (Coleoptera: Scarabaeidae) from Baltic amber, Palaeoentomology, 002, 425429, https://doi.org/10.11646/palaeoentomology.2.5.4, 2019.

Alekseev, V. I. and Bukejs, A.: A new Eocene Bacanius species (Histeridae: Dendrophilinae) from Baltic amber, Foss. Rec., 24, 93-99, https://doi.org/10.5194/fr-24-93-2021, 2021.

Alekseev, V. I. and Turkin, N. I.: Families of the order Coleoptera in raw Baltic amber, KSTU News, 12, 143-150, 2007.

Bechly, G. and Wichard, W.: Damselfly and dragonfly nymphs in Eocene Baltic amber (Insecta: Odonata), with aspects of their palaeobiology, Palaeodiversity, 1, 37-73, 2008.

Berendt, G.: Die im Bernstein befindlichen organischen Reste der Vorwelt gesammelt in Verbindung mit mehreren bearbeitet. Erster Band. Abtheilung I. Der Bernstein und die in ihm befindlichen Pflanzenreste der Vorwelt, Nikolaische Buchhandlung, Danzig, 1845.

Borsuk-Bialynicka, M., Lubka, M., and Bohme, W.: A lizard from Baltic amber [Eocene] and the ancestry of the crown group lacertids, Acta Palaeontol. Pol., 44, 349-382, 1999.

Bukejs, A. and Alekseev, V. I.: Acritus (s. str.) sutirca, holotype, 5541 [MAIG], X-ray micro-CT volume rendering of the habitus, TIB, https://doi.org/10.5446/52938, 2021a. 
Bukejs, A. and Alekseev, V. I.: Acritus (s. str.) sutirca, holotype, 5541 [MAIG], X-ray micro-CT volume rendering of the antennae, TIB, https://doi.org/10.5446/52939, 2021b.

Bukejs, A. and Alekseev, V. I.: Acritus (s. str.) sutirca, holotype, 5541 [MAIG], X-ray micro-CT volume rendering of the aedeagus, TIB, https://doi.org/10.5446/52940, 2021c.

Bukejs, A., Alekseev, V. I., and Pollock, D. A.: Waidelotinae, a new subfamily of Pyrochroidae (Coleoptera: Tenebrionoidea) from Baltic amber of the Sambian peninsula and the interpretation of Sambian amber stratigraphy, age and location, Zootaxa, 4664, 261-273, https://doi.org/10.11646/zootaxa.4664.2.8, 2019.

Casey, T. L.: Some random studies among the Clavicornia. Memoirs on the Coleoptera VII Lancaster, Pennsylvania, 35-283, 1916.

Gomy, I.: Contribution à la connaissance des Acritini éthiopiens (VIII). Description d'Acritus lamberti spec. nov. (Coleoptera: Histeridae), Zool. Med. Leiden, 68, 215-219, 1994.

Gyllenhal, L.: Insecta svecica descripta a Leonardo Gyllenhal. Classis I. Coleoptera sive Eleutherata, Tomus 1, Scaris, Litteris F. J. Leverentz, 1808.

Helm, O.: Beiträge zur Kenntiss der Insecten des Bernsteins, Schriften der Naturforschenden Gesellschaft in Danzig, Anlage C, N. S., 9, 220-231, 1896.

Hieke, F. and Pietrzeniuk, E.: Die Bernstein-Käfer des Museums für Naturkunde, Berlin (Insecta, Coleoptera), Mitteilungen aus dem Zoologischen Museum Berlin, 60, 297-326, 1984.

Kasiński, J. R., Kramarska, R., Słodkowska, B., Sivkov, V., and Piwocki, M.: Paleocene and Eocene deposits on the eastern margin of the Gulf of Gdańsk (Yantarny P-1 bore hole, Kaliningrad region, Russia), Geol. Q., 64, 29-53, https://doi.org/10.7306/gq.1513, 2020.

Klebs, R.: Über Bernsteineinschlüsse in allgemeinen und die Coleopteren meiner Bernsteinsammlung, Schriften der Physikalisch-ökonomischen Gesellschaft zu Königsberg i. Pr, 51, 217-242, 1910.

Kulicka, R. and Ślipiński, S. A.: A review of the Coleoptera inclusions in the Baltic amber, Prace Muzeum Ziemi, 44, 5-11, 1996.

Kryzhanovskij, O. L. and Reichardt, A. N.: Zhuki nadsemeystva Histeroidea (semeystva Sphaeritidae, Histeridae, Synteliidae), in: Fauna SSSR. Coleoptera, Vol. 5, Nauka, Leningrad, 1976.

Lackner, T.: Acritus komai - nový druh mrcinára pre Českú republiku (Coleoptera: Histeridae), Klapalekiana, 49, 227-228, 2013.

Lackner, T., Mazur, S., and Newton, A. F.: Family Histeridae Gyllenhal, 1808, in: Catalogue of Palaearctic Coleoptera. Volume 2. Hydrophiloidea - Staphylinoidea, parts 1-2, edited by: Löbl, I. and Löbl, D., Brill Publishers, Leiden, the Netherlands, 76-130, 2015.

LeConte, J. L.: Synopsis of the species of the histeroid genus Abraeus (Leach) inhabiting the United States, with descriptions of two nearly allied new genera, P. Acad. Nat. Sci. Phila., 6, 287292, 1853.

Lewis, G.: On certain new species of Coleoptera from Japan, Ann. Mag. Nat. Hist., 5, 459-467, 1879.

Lourenço, W. R.: A synopsis of the amber scorpions, with special reference to the Baltic fauna, Denisia, 26, Zugleich Kataloge der oberösterreichischen Landermuseen, 86, 131-136, 2009.

MacLeay, W. S.: Horae entomologicae: or essays on the annulose animals. Volume 1. Part 1, London, S. Bagster, 1819.

Martínez-Delclòs, X., Briggs, D. E. G., and Peñalver, E.: Taphonomy of insects in carbonates and amber, Palaeo- geogr. Palaeocl., 203, 19-64, https://doi.org/10.1016/S00310182(03)00643-6, 2004.

Mazur, S.: A concise catalogue of the Histeridae (Insecta: Coleoptera), Warsaw University of Life Sciences, SGGW Press, Warsaw, 2011.

Menge, A.: Lebenszeichen vorweltlicher, im Bernstein eingeschlossener Thiere. Programm der öffentlichen Prüfung der Schüler der Petrischule, A.W. Kafemann, Danzig, 1856.

Meunier, F.: Monographie des Cecidomyidae, des Sciaridae, des Mycetophilidae et des Chironomidae de l'ambre de la Baltique, Ann. Soc. Sci. Brux., 28, 12-275, 1904.

Nadein, K. S. and Perkovsky, E. E.: Small and common: the oldest tropical Chrysomelidae (Insecta: Coleoptera) from the lower Eocene Cambay amber of India, Alcheringa, 43, 597-611, https://doi.org/10.1080/03115518.2019.1622780, 2019.

Perkovsky, E. E. and Nel, A.: A new Rovno amber termite genus (Isoptera, Rhinotermitidae) from Styr river basin, Palaeontol. Electron., 24, 1-13, https://doi.org/10.26879/1127, 2021.

Polilov, A. A.: Small is beautiful: features of the smallest insects and limits to miniaturization, Annu. Rev. Entomol., 60, 103-121, https://doi.org/10.1146/annurev-ento-010814-020924, 2015.

Polilov, A. A. and Perkovsky, E. E.: New species of Late Eocene feather-winged beetles (Coleoptera, Ptiliidae) from Rovno and Baltic Amber, Paleontol. J., 38, 664-668, 2004.

Reitter, E.: Sechszehn neue Coleopteren aus Europa und den angrenzenden Ländern, Wiener Entolologische Zeitung, 23, 151160, 1904.

Sadowski, E.-M., Seyfullah, L. J., Schmidt, A. R., and Kunzmann, L.: Conifers of the "Baltic amber forest" and their palaeoecological significance, Stapfia, 106, 1-73, 2017.

Sadowski, E.-M., Schmidt, A. R., and Denk, T.: Staminate inflorescences with in situ pollen from Eocene Baltic amber reveal high diversity in Fagaceae (oak family), Willdenowia, 50, 405-517, https://doi.org/10.3372/wi.50.50303, 2020.

Schaufuss, L. W.: Die Scydmaeniden des baltischen Bernsteines, Nunquam Otiosus, 3, 561-586, 1890.

Seyfullah, L. J., Beimforde, C., Dal Corso, J., Perrichot, V., Rikkinen, J., and Schmidt, A. R.: Production and preservation of resins - past and present, Biol. Rev., 93, 1684-1714, https://doi.org/10.1111/brv.12414, 2018.

Sokolov, A. V. and Perkovsky, E. E.: The first Eocene species of Bacanius (Coleoptera: Histeridae: Dendrophilinae) from Rovno amber, Russian Entomological Journal, 29, 157-160, https://doi.org/10.15298/rusentj.29.2.06, 2020.

Spahr, U.: Systematischer Katalog der Bernstein- und Kopal-Käfer (Coleoptera), Stuttgarter Beiträge zur Naturkunde (Ser. B), 80, 1-107, 1981 .

Wang, M. and Xing, L.: A brief review of lizard inclusions in amber, Biosis: Biological Systems, 1, 39-53, https://doi.org/10.37819/biosis.001.01.0050, 2020.

Wenzel, R. L.: On the classification of the histerid beetles, Fieldiana Zoology, 28, 51-151, 1944.

Wenzel, R. L.: The histerid beetles of New Caledonia (Coleoptera: Histeridae), Fieldiana Zoology, 37, 601-634, 1955. 